\title{
Effect of the ketoprofen on the preemptive analgesia in female cats undergoing to ovariohysterectomy
}

\author{
Dayvid Vianêis Farias de Lucena ${ }^{1}$, Fernanda Vieira Henrique ${ }^{2 *}$, Amara Gyane Alves de Lima ${ }^{1}$, \\ Almir Pereira de Souza ${ }^{3}$, Pedro Isidro da Nóbrega Neto ${ }^{3}$
}

10.1590/0034-737X201764010003

\begin{abstract}
The objective of this study was to investigate the effect of the ketoprofen on the preemptive analgesia in female cats submitted to ovariohysterectomy. Sixteen healthy cats were distributed into two groups, with eight animals each, by means of a draw, in a preemptive group (PREG), in which the animal received ketoprofen $(1 \mathrm{mg} / \mathrm{kg}$ ) subcutaneously two hours before the surgery; and postsurgery group (POSG), in which ketoprofen $(1 \mathrm{mg} / \mathrm{kg}$ ) was administered subcutaneously immediately after surgery. In both groups, ketoprofen was given 24,48 and 72 hours after the first adminstration. Heart and respiratory frequencies and glycemia were measured in all animals during the days first ten postsurgery. Analgesia was measured by assigning scores at zero, two, four, six, 12, 24, 48, 72, 96, 120, 144, 168, 192, 216 and 240 hours after the surgical procedure. Statistical analysis was performed using two-way analysis of variance followed by Tukey's test to compare the moments and Student's t-test for comparison between groups. Pain scores were evaluated using test of UMann-Withney or Kruskall-Wallis, all at the 5\% level of significance. Pain scores were significantly lower in PREG in M0, M6, M72, M96 and M120. No significant difference was found in the levels of glycemia in comparison to baseline values. Ketoprofen promotes postsurgery analgesia in female cats submitted to ovariohysterectomy and preemptive and postsurgery administration provides an earlier reduction of pain scores when compared to postoperative administration, only.
\end{abstract}

Key words: non-steroidal anti-inflammatory; pain; feline.

\section{RESUMO}

\section{Efeito do cetoprofeno na analgesia preemptiva de gatas submetidas à ovário-histerectomia}

Objetivou-se investigar o efeito do cetoprofeno na analgesia preemptiva em gatas submetidas à ovário-histerectomia. Foram utilizadas 16 gatas, hígidas, distribuídas em dois grupos, com oito animais cada, por meio de sorteio, em: grupo preemptiva (GPRE), no qual se administrou cetoprofeno $(1 \mathrm{mg} / \mathrm{kg})$, por via subcutânea, duas horas antes do início da cirurgia; e grupo pós-operatório (GPOS), em que foi administrado cetoprofeno $(1 \mathrm{mg} / \mathrm{kg}$ ), também por via subcutânea, imediatamente após a cirurgia. Em ambos os grupos, as demais administrações de cetoprofeno foram realizadas $24,48 \mathrm{e}$ 72 horas após a primeira. Em todos os animais foram mensurados, durante os primeiros dez dias pós-operatórios, as frequências cardíaca e respiratória e a glicemia. A analgesia foi mensurada por meio de atribuição de escores, zero, duas, quatro, seis, 12, 24, 48, 72, 96, 120, 144, 168, 192, 216 e 240 horas após o procedimento cirúrgico. Na análise estatística utilizou-se a Análise de Variância de dois fatores seguida pelo teste de Tukey para comparar os momentos e o teste t de Student para comparação entre grupos. Os escores de dor foram avaliados pelo teste U-Mann-Withney ou KruskallWallis, todos ao nível de 5\% de significância. Os escores de dor foram significativamente menores no GPRE no M0, M6,

Submitted on February $26^{\text {th }}, 2015$ and accepted on December $16^{\text {th }}, 2016$

'Universidade Federal de Campina Grande, Centro de Saúde e Tecnologia Rural, Veterinary Hospital, Patos, Paraíba, Brazil. dayvidmv@gmail.com; amaragyane@hotmail.com

${ }^{2}$ Universidade Federal de Campina Grande, Programa de Pós-Graduação em Medicina Veterinária, Patos, Paraíba, Brazil. nandinhavh@gmail.com

${ }^{3}$ Universidade Federal de Campina Grande, Centro de Saúde e Tecnologia Rural, Patos, Paraíba, Brazil. almirpsouza@ibest.com.br; pedroisidro@ymail.com

*Corresponding author: nandinhavh@gmail.com

Rev. Ceres, Viçosa, v. 64, n.1, p. 018-024, jan/fev, 2017 
M72, M96 e M120. Não houve diferença significativa nos níveis de glicemia em relação aos valores basais. O cetoprofeno promove analgesia pós-operatória em gatas submetidas à ovário-histerectomia e a administração preemptiva e pósoperatória propicia uma redução mais precoce dos escores de dor, quando comparada à administração apenas pósoperatória.

Palavras-chave: anti-inflamatório não esteroidal; dor; felino.

\section{INTRODUCTION}

Analgesia provision is many times neglected in cats due to the lack of species-specific knowledge related to pain and drug metabolism in these animals (Taylor \& Robertson, 2004).

Ovarian hysterectomy is probably the most commonly surgery performed in felines, serving as an experimental model for several studies that evaluate clinical pain in this species (Teixeira et al., 2013). Nociceptive stimulation related to this type of surgery may persist until after 24 hours postsurgery, and may modify the behavior of the affected female cats (Fox \& Johnston, 1997).

Administration of analgesic drugs in a preemptive manner significantly reduces hyperalgesia when compared to postsurgery administration (Burton et al., 1999).

Low safety and the increase in the occurrence of side effects have limited the use of non-steroidal antiinflammatory drugs (NSAIDs) in cats (Staffieri et al., 2013), although there is a need to establish a safe and effective NSAID for analgesia in this species.

Ketoprofen is more effective than single doses of buprenorphine and pethidine in cats submitted to ovariohysterectomies (Slingsby \& Waterman-Pearson, 1998) and has efficacy equivalent to that of three other NSAIDs, carprofen, meloxicam and tolfenamic acid in the same species (Slingsby \& Waterman-Pearson, 2000).

The objective of this study was to investigate the effect of ketoprofen on preemptive analgesia in female cats submitted to elective ovary-hysterectomy.

\section{MATERIALAND METHODS}

The methodology of this work was approved by the Ethics Committee on the Use of Animals of the Universidade Federal Campina Grande, under protocol no. 106/2013.

Sixteen healthy female cats, at ages from six months to six years old, average weight of $3 \mathrm{~kg}$, were obtained from the owners in the city of Patos, Paraíba, Brazil. Prior to the experimental period, the animals underwent a fifteen-day adaptation period in individual cat kennels at the facilities in the Veterinary Hospital of the Universidade Federal Campina Grande, Patos Campus. Each owner signed a consent form, consenting to the participation of their animal in the experiment.
All animals were fed commercial diet and water ad libitum. Hemogram and renal and hepatic serum biochemistry were performed three days before the surgical procedure, in addition to clinical evaluation, to verify the hygiene of the animals.

Afterwards, the animals was directed to the surgical center and placed at dorsal decubitus position on an operating table lined with thermal mattress.

The animals were submitted to a 12 -hour food fasting and with no water for four hours. As pre-anesthetic medication, it was used atropine (Atropine $1 \%$ - Fagra) at the dose of $0.044 \mathrm{mg} / \mathrm{kg}$, subcutaneously, 15 minutes before of the anesthetic induction, which was performed with xylazine (Xilazin $2 \%$ - Syntec) at the dose of $1 \mathrm{mg} / \mathrm{kg}$, combined with ketamine (Ketamine 10\% - Syntec) in the same syringe, $15 \mathrm{mg} / \mathrm{kg}$ intramuscularly. After the prostration of the animal, the trichotomy of the ventral abdominal region and the region corresponding to the lumbosacral space was performed. Lumbosacral epidural anesthesia was performed with lidocaine without vasoconstrictor, (Xylestesin 2\% - Cristalia) at a dose of 4.4 $\mathrm{mg} / \mathrm{kg}$. After, the animals were transported to the surgical center and contained at supine position in a surgical table lined with a thermal mattress.

The ovary-hysterectomy technique used in the experiment was proposed by MacPhail (2013).

The animals were randomly distributed into two groups, with eight animals each, in: Preemptive Group (PREG) and Postsurgery Group (POSG). In PREG, ketoprofen (Ketojet $100 \mathrm{mg}$ - Agener Union) was administered subcutaneously at a dose of $1 \mathrm{mg} / \mathrm{kg}$. The first administration was carried out two hours before the beginning of the surgery and the other ones every 24 hours after the first, until the $3^{\text {rd }}$ postsurgery day. In the POSG, the same protocol described for the PREG was performed, by replacing the preemptive administration of ketoprofen with the one performed immediately after the surgery.

The following variables were measured in all animals 24 hours before the surgical procedure and during the first 10 postsurgery days, once a day, always at the same time: heart rate (HR), beats per minute (bpm), obtained by auscultation with a stethoscope; respiratory rate $(f)$, in movements per minute ( $\mathrm{mpm}$ ), obtained through inspection of thoracic movements. 
Pain level was measured immediately after the end of the surgery (M0) and two (M2), four (M4), six (M6), twelve (M12) and twenty four (M24) hours after it by using the scale for evaluation of acute pain in the immediate postsurgery period for felines (Chart 1), described by Brondani et al. (2011), in which the total sum of the score, denoting poor quality analgesia, would be 25 points. From the second postsurgery day, these variables were evaluated at 48 (M48), 72 (M72), 96 (M96), 120 (M120), 144 (M144), 168 (M168), 192 (M192), 216(M216) and 240 (M240) hours after the end of the procedure, using the scale for assessment of acute pain in cats from the second postsurgery day (Chart 2), also described by Brondani et al. (2011), in which the maximum score would be 15 points. If scores above 9 were obtained in the immediate postsurgery evaluation or score 5 in the evaluation of the second postsurgery day onwards, an analgesic rescue with morphine (Dimorf $0,1 \mathrm{mg} / \mathrm{mL}$ - Cristalia) would be used, at a dose of $0.5 \mathrm{mg} / \mathrm{kg}$ intramuscularly, consequently the animal would be removed from the experiment.

Serum glucose levels, in $\mathrm{mg} / \mathrm{dL}$, were measured from a blood sample (one drop), collected from the inner face of the ear, and read on a portable digital glycosometer (AccuChek Advantage - Roche Diagnóstica Brasil Ltda.). This parameter was evaluated 24 hours before the surgical procedure (T-24) and thereafter, it followed the same protocol established for the evaluation of analgesia degree.

Surgical time was computed in minutes by comparing the groups using Student's t-test and changes in body weights, in grams, by comparing the weights of the animals before and after the surgical intervention, using Student's t-test, as well.

Data was blindly collected always by the same evaluator, who did not know the protocol used in the experiment.

On the $10^{\text {th }}$ postsurgery day, after removal of cutaneous points, the animals were returned to their owners.

In order to compare the moments within the same group, it was used a two-factor analysis of variance with multiple comparisons by Tukey's test and to compare the two groups among each other, the Student's t-test was used. Pain scores were assessed by the U-Mann-Withney test for comparison between groups or Kruskall-Wallis for comparison between moments within each group. The statistical calculations were performed with the aid of the software program Bioestat 5.0 at the level of $5 \%$ of significance.

\section{RESULTS AND DISCUSSION}

All surgeries were performed according to the technique previously mentioned, without intercurrences. No statistical difference was found for the duration of the surgical procedure between the groups studied. The time required for ovariohysterectomy was $35.0 \pm 7.1$ minutes, on average, for the PREG and $41.9 \pm 10.7$ minutes for the POSG. Only the individual time of each surgical procedure varied.

No significant differences were observed between the animal weights before (PREG - $3.0 \pm 0.4 \mathrm{~kg}$; POSG - $2.89 \pm$ $0.4 \mathrm{~kg}$ ) and after (PREG - $2.9 \pm 0.4 \mathrm{~kg}$; POSG - $2.84 \pm 0.4 \mathrm{~kg}$ ) the surgical intervention, as well as there was no difference between the groups.

Statistical differences were observed in the evaluation of pain (Table 1) between the groups studied, in which pain scores were significantly lower in the PREG immediately after the end of surgery (M0) and six (M6), 72 (M72), 96 (M96) and 120 (M120) hours after the surgical procedure. In addition, despite the lack of significant difference at the other moments, it was noticed a tendency in the pain scores to be higher in the POSG, when compared to the PREG. This group presented values lower than those of the first evaluation of pain from the $3^{\text {rd }}$ postsurgery day (M72), a fact that did not occur in the POSG, in which the values only became smaller than the initial one from the $6^{\text {th }}$ postoperative day (M144). It is worth mentioning that, clinically, the PREG animals presented more comfort. According to Kamata et al. (2012) the presurgery administration of NSAIDs in dogs and cats provides better analgesia than only postsurgery administration. The method of pain evaluation used in the present study has already been tested and used by several authors, among them Taylor \& Robertson (2004) who state that behavioral observation is the best way to assess the degree of pain in cats.

In the POSG group, only one moment (M192) differed statistically from the baseline. The heart rate values were significantly lower in PREG when compared to POSG only in M168 and M216, but in all other moments there was a tendency of this parameter to be higher in POSG, although without statistical difference. Despite these differences, it is believed that stress due to physical restraint may have influenced the measured parameters.

The values found for respiratory rate, in both groups, (Table 1) were above the reference values for felines (Gonçalves, 2004) at all times, possibly due to the high environment temperature that was close to $36{ }^{\circ} \mathrm{C}$. No significant difference was found in relation to baseline values in both groups. Statistical differences were observed between the groups at moments M24 and M144, when the respiratory rate was significantly higher in the PREG when compared to the POSG, but without clinical relevance, since the basal values were already high, probably due to the stress experienced by the animals during the measurement of parameters and physical restraint. In this study, heart and respiratory rate 
Chart 1: Scale for evaluation of acute pain in felines: immediate post-surgery

\section{Factor 1: Psychomotor alteration}

\section{Posture}

(0) Normal (any position, comfort apearance, relaxed muscles)

(1) Stiff (lateral decubitus, paws stretched in fixed position)

(2) Tense (any position, the animal appear to be afraid, not willing to move, tense muscles).

(3) Different postures for trying to get a comfortable position

\section{Comfort}

(0) Asleep or awake and when stimulated, interested in the environment

(1) Asleep or awake and when stimulated, not interested in the environment

(2) Agitated, uncomfortable, restless (gets up and lies down continuously)

\section{Movement}

(0) Regular quantity of movements

(1) Fewer quantity of movements

(2) Reluctant for moving

(3) Frequent changing of position

\section{Mental condition}

Mark the presence of the mental status related below:

A) Satisfied: interested in the environment, positive interaction with the evaluator, responsive, alert, not aggressive

B) Disinterested: it does not interact with the evaluator

C) Indifferent: not responsive to the environment

D) Nervous and/or Anxious and/or Scared (tendency to hide or try to scape)

E) Aggressive

(0) Presence of mental condition A

(1) Presence of 1 of the mental conditions: B, C, D or E

(2) Presence of 2 mental conditions: B, C, D or E

(3) Presence of 3 or all mental conditions: B, C, D or E

\section{Behavior miscellany}

Mark the presence of the behavior described below:

- Moves the tail quickly and continuously

- Stretches and contracts hind legs

- Presence of partly closed eyes

- Licks the wounded area and/or uses the mouth and teeth in the wounded area

(0) All behaviors related above are absent

(1) Presence of 1 of the behaviors related above

(2) Presence of 2 of the behaviors related above

(3) Presence of 3 of the behaviors related above

Factor 1: (total of 14 points)

\section{Factor 2: Protection behavior. Interaction - Response to the touching Surgical wound touching}

(0) No response or no alteration in relation to the touching on the pre-procedure surgical wound

(1) When the wound is touched - it does not respond

When the wound is pressed-it retracts itself and may vocalize

(2) When the wound is touched - it retracts itself and may vocalize

When the wound is pressed - it escapes and move the head towards the wound; it may vocalize and/or try to bite

(3) when the wound is touched or pressed - it escapes and moves the head quickly and intensively towards the wound; it many vocalize and/or tries to bite.

(4) When the evaluator approaches - it vocalizes and/or tries to bite

\section{Touching of abdomen and flank}

(0) Lack of abdominal tension or no alteration in relation to response from the animal to pre-procedure touching of abdomen and flank

(1) Presence of abdominal tension, it may vocalizes or tries to bite when abdomen and/or flank are touched

(2) when evaluator approaches - it vocalizes and or tries to bite

Factor 2: (total of 6 points) 


\section{Factor 3: Physiological alteration}

\section{Appetite}

(0) Normorexia

(1) Hyporexia

(2) Anorexia

Factor 3: (total of 2 points)

\section{Factor 4: Pain expression.}

\section{Vocalization}

(0) It does not vocalize; it purrs when touched; it meows interacting with the evaluator

(1) It vocalizes when the evaluator approaches and calms down when touched

(2) It vocalizes when the evaluator approaches and it does not calm down when touched

(3) It vocalizes spontaneously (it groans or growls or sibyls or purrs)

Factor 4: (total of 3 points)

Source: Brondani et al. (2011).

Chart 2: Scale for evaluation of acute pain in cats: $2^{\text {nd }}$ post-surgery day

\section{Factor 1: Psychomotor Alteration}

\section{Posture}

(0) Normal (any position, comfort apearance, relaxed muscles)

(1) Stiff (lateral decubitus, paws stretched in fixed position)

(2) Tense (any position, the animal seems to be afraid, not willing to move, tense muscles).

(3) Different postures in trying to get a comfortable position

\section{Movement}

(0) Regular quantity of movements

(1) Fewer quantity of movements

(2) Reluctant for moving

(3) Frequent changing of position

\section{Mental condition}

Mark the presence of the mental status related below:

A) Satisfied: interested in the environment, positive interaction with the evaluator, responsive, alert, not aggressive

B) Disinterested: it does not interact with the evaluator

C) Indifferent: not responsive to the environment

D) Nervous and/or Anxious and/or Scared (tendency to hide or tries to scape)

E) Aggressive

(0) Presence of mental condition A

(1) Presence of 1 of the mental conditions: B, C, D or E

(2) Presence of 2 mental conditions: B, C, D or E

(3) Presence of 3 or all mental conditions: B, C, D or E

Score: Factor 1 (total of 9 points)

\section{Factor 2: Protection behavior}

\section{Surgical Wound Touching}

(0) No response or no alteration in relation to the touching on the pre-procedure surgical wound

(1) When the wound is touched - it does not respond

When the wound is pressed- it retracts itself and may vocalize

(2) When the wound is touched - it retracts itself and may vocalize

When the wound is pressed - it escapes and moves the head towards the wound; it may vocalize and/or try to bite

(3) when the wound is touched or pressed - it escapes and moves the head quickly and intensively towards the wound; it may vocalize and/or tries to bite.

(4) When the evaluator approaches - it vocalizes and/or tries to bite

\section{Touching of abdomen and flank}

(0) Lack of abdominal tension or no alteration in relation to response from the animal to pre-procedure touching of abdomen and flank

(1) Presence of abdominal tension, it may vocalizes or tries to bite when abdomen and/or flank are touched

(2) when evaluator approaches - it vocalizes and or tries to bite

Factor 2: (total of 6 points)

Source: Brondani et al. (2011).

Rev. Ceres, Viçosa, v. 64, n.1, p. 018-024, jan/fev, 2017 
Table 1: Mean value and standard deviation of pain scores during postsurgery post-operative period, heart frequency (HF), respiratory frequency (RF) and glycemia before and after ovariohysterectomy surgery in female cats treated with ketoprofen administered before and after (PREG) or only after surgery (POSG)

\begin{tabular}{|c|c|c|c|c|c|c|c|c|}
\hline \multirow[t]{2}{*}{ Moments } & \multicolumn{2}{|c|}{ Pain score } & \multicolumn{2}{|c|}{$\begin{array}{l}\text { Heart frequency } \\
\text { (bpm) }\end{array}$} & \multicolumn{2}{|c|}{$\begin{array}{l}\text { Respiratory frequency } \\
\text { (mpm) }\end{array}$} & \multicolumn{2}{|c|}{$\begin{array}{r}\text { Glycemia } \\
\text { (mg/dl) }\end{array}$} \\
\hline & PREG & POSG & PREG & POSG & PREG & POSG & PREG & POSG \\
\hline M-24 & - & - & $160 \pm 23$ & $160 \pm 3$ & $67 \pm 24$ & $51 \pm 18$ & $66 \pm 6$ & $68 \pm 34$ \\
\hline M0 & $1.7 \pm 0.7^{\#}$ & $3.0 \pm 1.0$ & - & - & - & - & $79 \pm 13$ & $86 \pm 42$ \\
\hline M2 & $1.0 \pm 0.9$ & $2.2 \pm 1.7$ & - & - & - & - & $83 \pm 23$ & $88 \pm 25$ \\
\hline M4 & $1.7 \pm 1.8$ & $3.0 \pm 2.2$ & - & - & - & - & $70 \pm 11$ & $85 \pm 33$ \\
\hline M6 & $1.2 \pm 1.6^{\#}$ & $2.9 \pm 1.9$ & - & - & - & - & $62 \pm 5$ & $65 \pm 27$ \\
\hline M12 & $1.1 \pm 1.2$ & $2.1 \pm 1.6$ & - & - & - & - & $62 \pm 5$ & $73 \pm 21$ \\
\hline M24 & $1.1 \pm 1.0$ & $1.1 \pm 1.1$ & $146 \pm 32$ & $157 \pm 21$ & $67 \pm 15^{\#}$ & $40 \pm 14$ & $58 \pm 10$ & $59 \pm 30$ \\
\hline M48 & $0.5 \pm 0.7$ & $1.0 \pm 1.2$ & $140 \pm 17$ & $152 \pm 27$ & $51 \pm 22$ & $43 \pm 18$ & $59 \pm 11$ & $65 \pm 24$ \\
\hline M72 & $0.0 \pm 0.0^{* \#}$ & $1.2 \pm 1.0$ & $140 \pm 17$ & $156 \pm 15$ & $59 \pm 22$ & $44 \pm 21$ & $67 \pm 15$ & $67 \pm 20$ \\
\hline M96 & $0.0 \pm 0.0^{* \#}$ & $0.9 \pm 0.8$ & $140 \pm 9$ & $128 \pm 16$ & $58 \pm 17$ & $44 \pm 10$ & $63 \pm 11$ & $67 \pm 20$ \\
\hline M120 & $0.0 \pm 0.0^{* \#}$ & $0.9 \pm 1.1$ & $136 \pm 1$ & $131 \pm 23$ & $62 \pm 13$ & $54 \pm 16$ & $56 \pm 13$ & $77 \pm 43$ \\
\hline M144 & $0.0 \pm 0.0 *$ & $0.6 \pm 1.0 *$ & $119 \pm 7 *$ & $131 \pm 25$ & $60 \pm 12^{\#}$ & $41 \pm 19$ & $57 \pm 7$ & $69 \pm 38$ \\
\hline M168 & $0.0 \pm 0.0 *$ & $0.6 \pm 1.0 *$ & $121 \pm 9 * \#$ & $136 \pm 25$ & $56 \pm 17$ & $51 \pm 33$ & $55 \pm 8$ & $70 \pm 36$ \\
\hline M192 & $0.0 \pm 0.0 *$ & $0.5 \pm 0.7 *$ & $119 \pm 9 *$ & $122 \pm 11 *$ & $53 \pm 16$ & $39 \pm 19$ & $55 \pm 9$ & $71 \pm 35$ \\
\hline M216 & $0.0 \pm 0.0 *$ & $0.4 \pm 0.7 *$ & $117 \pm 13^{* \#}$ & $140 \pm 14$ & $57 \pm 16$ & $58 \pm 18$ & $56 \pm 9^{\#}$ & $82 \pm 48$ \\
\hline M240 & $0.0 \pm 0.0 *$ & $0.4 \pm 0.7 *$ & $128 \pm 12$ & $146 \pm 12$ & $54 \pm 13$ & $50 \pm 14$ & $56 \pm 9^{\#}$ & $88 \pm 44$ \\
\hline
\end{tabular}

\#- Statistically different from POSG groups, according to Student's t test or U-Mann-Withney for scores of pain (p < 0.05 ).

*- Statistically different from the first value of the same group, according to the two-factor ANOVA, followed by the test of Tukey or according to the test of Kruskall Wallis for scores of pain $(\mathrm{p}<0.05)$.

measurements did not seem to be reliable discriminators for the evaluation of postoperative pain, as reported in the study by Gauthier et al. (2014) who state that physiological variables are not sound indicators of pain in cats since they are strongly influenced by other factors.

In the study reported in this paper, it was observed that hypoglycemia occurred in both groups (Table 1) (Faria, 2009) at almost all times. Hypoglycemia observed at baseline was probably due to fasting experienced by animals. In some postoperative moments, glycemia presented values within the normal range, but in others, hypoglycemia was also observed. Statistical difference was found between groups only from M216, where levels glycemia were lower in PREG when compared to POSG. The absence of significant difference in glycemia values in relation to baseline suggests that ketoprofen promoted good quality analgesia, corroborating the results obtained in this study in the analysis of analgesia and agreeing with Dobbins et al. (2002), who state that this drug provides postoperative analgesia in cats in both soft tissue surgeries and orthopedic procedures.

\section{CONCLUSIONS}

Ketoprofen promotes postoperative analgesia in female cats submitted to ovariohysterectomy and pre-emptive and postsurgery administration leads to earlier reduction of pain scores when compared to postsurgery administration, only.

\section{REFERENCES}

Brondani JT, Luna SPL \& Padovani CR (2011) Refinement and initial validation of a multidimensional composite scale for use in assessing acute postoperative pain in cats. American Journal Veterinary Research, 72:174-183.

Burton AW, Lee DH, Saab C \& Chung JM (1999) Preemptive intrathecal ketamine injection produces a long-lasting decrease in neuropathic pain behaviors in a rat model. Regional Anesthesia Pain Medicine, 24:208-213.

Dobbins S, Brown NO \& Shofer FS (2002) Comparison of the effects of buprenorphine, oxymorphone hydrochloride, and ketoprofen for postoperative analgesia after onychectomy or onychectomy and sterilization in cats. Journal of the American Animal Hospital Association, 38:507-514.

Faria VP (2009) Avaliação Clínica, Laboratorial e Ecocardiográfica de Gatos Domésticos Hipertireóideos no período entre 2007 e 2008. Dissertação de Mestrado. Universidade Federal Rural do Rio de Janeiro, Seropédica.110p.

Macphail CM (2013) Surgery of the Reproductive and Genital Systems. In: Fossum TW, Dewey CW, Horn CV, Johnson AL, Macphail CM, Radlinsky MG, Schulz KS \& Willard MD (Eds). Small Animal Surgery. $4^{\text {th }}$ ed. St. Louis, Elsevier. p.780853 .

Fox SM \& Johnston SA (1997) Use of carprofen for the treatment of pain and inflammation in dogs. Journal of the American Veterinary Medical Association, 210:1493-1498.

Gauthier O, Holopherne-Doran D, Gendarme T, Chebroux A, Thorin C, Tainturier D \& Bencharif D (2014) Assessment of Postoperative Pain in Cats After Ovariectomy by Laparoscopy, Median Celiotomy, or Flank Laparotomy. Veterinary Surgery, 9999:01-08. 
Gonçalves RC (2004) Semiologia do sistema respiratório. In Feitosa FLF (Ed.) Semiologia Veterinária: arte do diagnóstico. São Paulo, Roca. p. 313-331.

Kamata M, King JN, Seewald W, Sakakibara N, Yamashita K \& Nishimura R (2012) Comparison of injectable robenacoxib versus meloxicam for peri-operative use in cats: Results of a randomised clinical trial. The Veterinary Journal, 193:114-118.

Slingsby LS \& Waterman-Pearson AE (1998) Comparison of pethidine, buprenorphine and ketoprofen for postoperative analgesia after ovariohysterectomy in the cat. Veterinary Record, 143:185-189.

Slingsby LS \& Waterman-Pearson AE (2000) Postoperative analgesia in the cat after ovariohysterectomy by use of carprofen, ketoprofen, meloxicam or tolfenamic acid. Journal of Small Animal Practice, 41:447-450
Staffieri F, Centonze P, Gigante G, De Pietro L \& Crovace A (2013) Comparison of the analgesic effects of robenacoxib, buprenorphine and their combination in cats after ovariohysterectomy. The Veterinary Journal, 197:363-367.

Taylor PM \& Robertson SA (2004) Pain management in cats Past, present and future. Part 1. The cat is unique. Journal of Feline Medicine and Surgery, 6:313-320.

Teixeira LR, Luna SPL, Taffarel MO, Lima AFM, Sousa NR, Joaquim JGF \& Freitas PM (2013) Comparison of intrarectal ozone, ozone administered in acupoints and meloxicam for postoperative analgesia in bitches undergoing ovariohysterectomy. The Veterinary Journal, 197:794-799. 